\title{
Effects of Aquarobic Exercise on Body Composition and Cardiovascular Index in Elderly Women
}

\author{
Chankyu KIM ${ }^{\mathrm{a}}$, Byunghoon LEE
}

${ }^{\mathrm{a}}$ Gwangju Health University

Objective: The community has implemented a variety of exercise programs for the elderly population. However, studies comparing changes in the cardiovascular system through body composition and blood analysis after applying aqua aerobic exercise are insufficient. The purpose of this study was to investigate the effect of a 12 weeks aqua exercise on body composition and cardiovascular index in elderly women.

Design: Non-equivalence pre-post design.

Methods: Thirty elderly women were assigned to aquarobic group $(n=15)$ and control group $(n=15)$. The aquarobic exercise was 60 minutes per every session, 2times per week, for 12weeks. Weight, skeletal muscle mass, body fat percentage, total cholesterol, triglyceride, HDL cholesterol, and LDL cholesterol were measured before and after the exercise program. Paired and independent t-tests were performed using SPSS program.

Results: The result showed was weight $(\mathrm{p}<0.05)$, body fat percentage $(\mathrm{p}<0.05)$, total cholesterol $(\mathrm{p}<0.05)$, triglyceride $(\mathrm{p}<0.05)$, HDL cholesterol $(\mathrm{p}<0.05)$, and LDL cholesterol $(\mathrm{p}<0.05)$ were significantly decreased and skeletal muscle mass $(\mathrm{p}>0.05)$ was not significantly increased after aquatic exercise program.

Conclusions: According to the study result, aqua exercise program made a positive effect in the improvement of obesity and cardiovascular function in elderly women. Therefore, we suggest that you actively consider implementing the Aquarobic exercise program when operating the community health promotion program in the future. In addition, in future studies, comparative studies according to various ages and genders and studies on the effects of aqua aerobic exercise as a community exercise program for chronically illness patients are needed.

Key Words: Aquarobic, Body composition, Cardiovascular index, Elderly women, Exercise

\begin{abstract}
서론
현대 사회는 경제발전과 생활수준 향상 및 의학 기술의 발달로 노인 인구가 빠르게 증가하고 있다. 통계청이 발 표한 2020년 고령자 통계에 따르면 우리나라 총 인구 중 65세 이상이 차지하는 비율은 $15.7 \%$ 로 나타났다[1]. 이러 한 노인 인구의 증가는 여러 가지 사회적, 경제적 문제를 발생시키며, 국가적으로 가장 큰 문제는 노인들의 만성질 환 증가로 인한 의료비 증가 뿐만 아니라 건강 및 사회복 지를 위한 예산부족이다[2]. 이러한 문제의 해결을 위해 건강수명을 연장시키고 만성 질환으로부터 고통 받는 기 간을 줄이는 것이 중요한 국가적 문제로 등장하였다[2].
\end{abstract}

나이의 증가에 따른 노화는 신체, 사회, 심리적으로 새로 운 문제들이 야기되고 있다. 특히 노화로 인한 노인의 근 육·신경계 및 호흡·순환기 계통의 기능저하는 자립생활 을 어렵게 함으로 신체적 능력을 감소시키고[3], 신체활동 의 제한을 초래한다. 신체활동은 에너지 소비를 담당하는 중요한 요소로서 신체활동의 부족은 원활한 물질 대사능 력을 저하시켜 비만과 당뇨, 심혈관 질환 등 각종 질병을 야기시킬 수 있다[4]. 특히 노인들의 비만은 과다체중, 복 부비만, 혈중 지질 성분의 증가, 심혈관계의 기능 수준 저 하등과 함께 나타나며[5], 관절에 무리를 주고 불편한 거 동은 운동량을 떨어뜨려 비만의 악순환을 초래한다[6].

노화에 따른 신체능력감소와 심혈관계 질환 및 비만 예

Received: Jun 23, 2021 Revised: Sep 5, 2021 Accepted: Sep 14, 2021

Corresponding author: Byunghoon LEE (ORCID https://orcid.org/0000-0003-1331-6779)

Department of Physical Therapy. Gwangju Health University. 73, Bungmun-daero 419 beon-gil, Gwangsan-gu [61268]

Tel: +82-10-7174-3669, E-mail: rukas1024@nate.com

This is an Open-Access article distributed under the terms of the Creative Commons Attribution Non-Commercial License (http://creativecommons.org/licenses/ by-nc/4.0) which permits unrestricted non-commercial use, distribution, and reproduction in any medium, provided the original work is properly cited.

Copyright $(2021$ Korean Academy of Physical Therapy Rehabilitation Science 
방 방법으로 식이 요법과 운동 요법으로 나눌 수 있다. 식이 요법은 섭취 열량을 제한하는 방법으로 일시적인 체중 감량 의 효과는 크게 나타나지만 근육 손실로 인한 체중의 감소 와 근 기능 장애를 유발시킴으로 노인에게는 적합하지 않다 [7]. 반면, 운동 요법은 수면의 질 향상, 우울증 감소, 기능 적 역량의 유지 또는 증가, 행동장애 저하 등 대상자들에게 자신감과 성취감을 제공함으로 노인들에게 적합하다[8]. 특 히 규칙적인 유산소 운동은 지방산을 산화시키고 혈당 사용 을 증가시켜 인슐린 기능을 향상시키며, 대사성 질환과 관 계된 비만 개선에 긍정적이다고 보고되었고[9], 규칙적인 신 체활동과 운동 트레이닝은 인슐린 저항을 개선시켜 혈당 조 절에 도움을 주며 혈중 지질인 중성지방(TG), 총 콜레스테 롤(Total Cholesterol, TC), 고밀도 지단백 콜레스테롤(High density lipoprotein cholesterol, HDL-C), 저밀도 지단백 콜레스테롤(Low density Lipoprotein cholesterol, LDL-C), 인슐린 저항성(Homeostatic Model Assessment for Insulin Resistance, HOMA-IR)을 개선시킨다고 보고된 바 있다[10]. 노인들의 체력증진 프로그램은 유산소성 운동, 저항성 운동, 유연성운동 및 복합운동 등의 다양한 형태로 이루 어져 신체기능 향상과 건강을 위해하는 요인을 효과적으 로 감소시키는 것으로 알려져 있다[11], 하지만 노인들은 각종 신체기능의 저하와 무릎관절의 통증 그리고 낙상의 위험 때문에 적극적으로 신체활동을 하는데 제약을 받고 있다[12]. 이러한 측면에서 아쿠아로빅 운동은 부력, 정수 압, 수온 등 매개물의 물리적 특성을 활용하여 통증을 감 소시키고 관절의 부담을 경감시키는 등 지상에서보다 에 너지 소모가 높고, 물의 저항을 이용한 골격근 기능 강화 에도 유용한 수단이 될 수 있다[13].

미국의 Arthritis Foundation에서 1970년대 중반 개발 되어 보급되기 시작한 아쿠아로빅 운동은 물을 활용하여 상해에 따른 통증을 감소시키고, 다른 운동에서 쉽게 발 생할 수 있는 근육의 긴장이나 재손상의 위험을 예방하며, 운동의 효과 가 높은 것으로 알려져 있다[14]. 가슴 높이 의 물속에서 경쾌하게 음악에 맞춰 걷기(전,후), 점프, 스 윙, 차기, 비틀기 등의 동작을 연속적으로 수행하면서 관 절의 부하를 줄이면서 운동 효과를 얻을 수 있어 노인 신 체기능을 효과적으로 향상시킬 수 있다[15]. 정덕조 등 [16]은 아쿠아로빅 운동을 통해 심폐지구력, 근지구력, 근력
의 향상과 체중감소, 유연성 증진에 효과가 있다고 보고 하였으며, 황연희와 김동희[2]는 비만 여성을 대상으로 한 연구에서 신체구성 성분 및 혈중지질에 긍정적인 효과가 있다고 보고하였다. 김인숙[17]은 관절염 환자를 대상으 로 아쿠아로빅 운동을 시행한 연구를 보고하였고, Wilder 와 Brennan[18]은 부상선수의 통증 감소를 목적으로 연 구를 실시한 바 있다.

이처럼 다양한 연령군을 대상으로 아쿠아로빅 운동의 효과에 대하여 많은 연구가 진행되고 있음에도 불구하고 지역 내 보건소의 건강증진 프로그램을 통한 아쿠아로빅 운동의 효과에 대한 연구가 부족한 실정이다.

따라서 본 연구는 보건소 건강증진 프로그램으로 아쿠 아로빅 운동을 시행하여 노인 여성의 신체조성 및 심혈관 계 위험인자에 미치는 효과를 확인하고 향후 지역 보건소 의 건강증진 프로그램으로서 아쿠아로빅 운동에 대한 기 초자료로 활용하고자 한다.

\section{연구 방법}

\section{연구 설계}

본 연구는 아쿠아로빅 운동에 따른 신체조성과 심혈관 계 지표의 변화를 알아보기 위한 유사 실험 연구로, 두 집 단의 사전 · 후 설계 방법을 사용하였다. 대상자에게 단일 눈가림법을 사용하였으며, 연구에 참여하기로 동의한 30 명을 대상으로 진행하였다. 대상자는 아쿠아로빅 운동군, 대조군으로 각 15 명씩 분류하였다. 운동 프로그램으로 총 12 주 동안 주 2 회, 총 24 회의 중재를 적용한 후, 각 그룹 의 중재 효과를 비교하기 위해 사전, 후 모두 체성분 분석 기와 혈액 분석을 통해 실시하였다.

\section{연구 대상}

본 연구의 대상자는 $\mathrm{A}$ 광역시에 위치한 보건소 건강증 진 프로그램 대상자 중 본 연구에 대한 설명을 듣고, 연구 에 참여하기로 동의한 60 세 이상 75 세 미만의 노인 여성 30 명 중 연구의 의의와 목적을 설명하고 출석률 $80 \%$ 이상 15 명을 운동군으로 선정하였고, 대조군은 경로당에서 규칙 적인 신체활동의 경험이 없는 15 명으로 하였다(Table 1).

Table 1. General Characteristics of subjects

$(\mathrm{n}=30)$

\begin{tabular}{lll}
\hline Characteristics & control group $\left(\mathbf{n}_{\mathbf{1}}=\mathbf{1 5}\right)$ & Aquarobic group $\left(\mathbf{n}_{\mathbf{2}}=\mathbf{1 5}\right)$ \\
\hline Age $($ years $)$ & $68.66(7.77)^{\mathrm{a}}$ & $67.53(3.73)$ \\
Height $(\mathrm{cm})$ & $155.80(4.55)$ & $156.66(4.73)$ \\
Weight $(\mathrm{kg})$ & $57.13(6.35)$ & $59.00(5.14)$ \\
\hline
\end{tabular}

The values are presented mean (SD) ${ }^{\mathrm{a}}$ 


\section{아쿠아로빅 운동 프로그램 구성}

대상자의 실험처치는 보건소 내 건강증진교실에서 신 체조성 및 체력 검사를 행하였다. 수중운동 프로그램은 보건소 관할의 수영장에서 (사)한국아쿠아 운동협회에 소 속된 전문 강사가 직접 시행하였다. 운동 프로그램은 Jones와 Rose[19]의 프로그램에 근거하여 본 연구 목적에 맞게 수정·보완 하였으며, 운동강도는 ACSM[20]을 근 거로 하였다. 수중운동 프로그램은 준비운동 10 분, 본 운 동 40 분, 정리운동 10 분으로 하여 1 일 60 분, 주 2 회, 총 12 주 동안 시행하였다.

준비운동은 $120 \mathrm{BPM}$ 으로 하여 관절의 무리가 없이 제자리 걷기, 뛰기 동작으로 신체의 체온을 높인 다음 동적 스트레칭으로 10 분간 실시하였다. 본 운동은 근지구력과 근력을 강화시키기 위한 밸런스 링과 누들을 사용 할 때 는 120-130 BPM, 심폐지구력 운동시에는 130-150 BPM 으로 사용하였으며, 1-2주 동안은 적응기로 RPE 9-10(아 주 가볍다)의 강도로 하였고, 3-6주는 RPE 11-12(가볍 다), 7-12주는 RPE 13-14(약간 힘들다)의 운동 강도로 점진적 증가 방법을 적용하였다.

정리 운동은 걷기와 정적 스트레칭을 110-120 BPM으 로 10 분간 실시하였다. 구체적인 프로그램은 <Table 2>
와 같다.

\section{측정방법 및 도구}

\section{신체조성}

신체조성 측정은 생체전기저항법(Bioelectrical impedance analysis)을 이용한 체성분 분석기(Inbody520, Inbody, Korea)를 이용하여 체중(weight), 체지방율(\%fat), 제지방 량(lean-body mass) 등을 측정하였다.

대상자의 손과 발을 전해질 티슈(electrolytic tissue)로 닦은 다음 두 손으로 손잡이 전극을 잡고 양발을 가슴넓 이로 발바닥 전극을 밟은 채 양 팔을 가볍게 내린 채 정 면을 응시하도록 하여 측정하였다. 측정 전날 가급적 힘 든 신체활동은 피하도록 하고, 측정 2 시간 전 음식물과 카페인은 금지시키고, 복장은 간편한 운동복 차림으로 측 정 하였다[8].

\section{심혈관계 지표}

본 연구에서는 운동 전과 운동 후 2 회에 걸쳐 심혈관 지표를 확인하고자 채혈 및 분석을 시행하였다. 혈액 채 취는 임상병리사 면허를 취득한 후 혈액분석 업무를 담당

Table 2. Aquarobic exercise program

\begin{tabular}{|c|c|c|c|c|}
\hline order & contents & Intensity & tempo/bpm & Time/min \\
\hline Warm-up & $\begin{array}{l}\text { Slow walking } \\
\text { bounce } \\
\text { Stretching }\end{array}$ & 7-9 RPE & 120 & 10 \\
\hline $\begin{array}{l}\text { Main } \\
\text { Exercise }\end{array}$ & $\begin{array}{l}\text { Jogging } \\
\text { Jumping jack } \\
\text { Corss Contry } \\
\text { Pendulum } \\
\text { Step side to side } \\
\text { Back Kick } \\
\text { skipping Laps } \\
\text { Leg swing and Curl } \\
\text { Twist heel and toe Jig } \\
\text { Soccer Kick and Russian Kick } \\
\text { chest fly } \\
\text { Hamstring extensions } \\
\text { Snap kicks } \\
\text { Jab punches } \\
\text { jumping squats }\end{array}$ & $\begin{array}{l}\text { 7 12week } \\
\text { 13-14 RPE }\end{array}$ & $130 \sim 150$ & 40 \\
\hline Cool-down & $\begin{array}{l}\text { Slow walking } \\
\text { bounce } \\
\text { Stretching }\end{array}$ & 7-9 RPE & 120 & 10 \\
\hline
\end{tabular}


하고 있는 전문가에 의해 수행되었다. 채혈 당일 12 시간 공복상태를 유지한 후 채혈 30 분전 실험실에서 안정상태 를 유지하도록 한 후, 위팔 정맥에서 1 회용 주사기를 이 용하여 $10 \mathrm{ml}$ 씩 채혈하였다. 채혈된 혈액은 원심분리기를 이용하여 $3000 \mathrm{RPM}$ 으로 15 분간 혈청을 분리한 후 분석

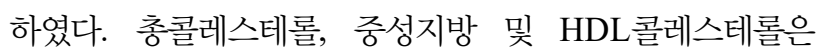
ADVIA (ADVIA1650, Bayer, Japan) 분석장비를 이용 하여 Enzymatic, colorimetry 검사법에 의해 측정하였다. LDL 콜레스테롤은 ADVIA (ADVIA 1650, Bayer, Japan) 분석장비를 이용하여 Elimination enzymatic assay 검사법에 의해 측정하였다.

\section{자료 분석}

본 연구에서 측정된 모든 자료는 SPSS (Ver 17.0, SPSS Inc., U.S.A) 프로그램을 사용하여 평균과 표준편차로 산 출하였다. 정규성 검증을 위해 Kolmogorov-Smirnov test 를 이용하였다. 대상자의 일반적 특성은 기술통계를 사용 하였으며, 모든 측정 자료들이 정규분포를 보였고, 정규분 포를 보였기 때문에 모수적 검정법을 이용하여 평균값들 의 비교를 실시하였다. 아쿠아로빅 운동군과 대조군의 운 동 프로그램의 신체조성과 심혈관계 지표에 대한 운동 전, 후 비교는 Paired t-test를 시행하였으며, 그룹간의 차이는 Independent t-test를 시행하였다. 자료의 모든 통계학적 유의수준은 $\alpha=0.05$ 로 하였다.

\section{연구 결과}

\section{신체조성의 변화}

체중은 운동군은 $59.00 \pm 5.14 \mathrm{~kg}$ 에서 12주 운동 후 $57.93 \pm 5.03 \mathrm{~kg}$ 로 감소하였고 $(\mathrm{p}<0.05)$, 대조군은 $57.13 \pm 6.35$ $\mathrm{kg}$ 에서 $57.06 \pm 5.37 \mathrm{~kg}$ 로 유의한 차이가 없었다 $(\mathrm{p}>0.05)$. 골격근량에서는 운동군은 $21.73 \pm 2.93 \mathrm{~kg}$ 에서 12 주 운 동 후 $22.33 \pm 2.91 \mathrm{~kg}$ 로 유의한 차이가 없었고 $(\mathrm{p}>0.05)$, 대조군은 $21.00 \pm 2.36 \mathrm{~kg}$ 에서 $21.20 \pm 2.45 \mathrm{~kg}$ 으로 통계적 으로 유의한 차이가 없었다 $(\mathrm{p}>0.05)$.

체지방량에서는 운동군은 $32.20 \pm 4.61 \mathrm{~kg}$ 에서 12주 운 동후 $30.06 \pm 3.75 \mathrm{~kg}$ 로 통계적으로 유의하게 감소하였고 $(\mathrm{p}<0.001)$, 대조군은 $32.26 \pm 4.86 \mathrm{~kg}$ 에서 $32.80 \pm 4.82 \mathrm{~kg}$ 로 통계적으로 유의한 차이가 없었다 $(\mathrm{p}>0.05)$.

\section{심혈관계 지표의 변화}

총콜레스테롤은 운동군이 $191.33 \pm 34.06 \mathrm{mg} / \mathrm{dl}$ 에서 12 주 운동 후 $175.60 \pm 30.50 \mathrm{mg} / \mathrm{dlmg} / \mathrm{dl}$ 로 통계적으로 유의 하게 감소하였고 $(\mathrm{p}<0.001)$, 대조군은 $\quad 190.93 \pm 32.78$ $\mathrm{mg} / \mathrm{dl}$ 에서 $191.00 \pm 32.14 \mathrm{mg} / \mathrm{dl}$ 로 통계적으로 유의한 차 이가 없었다 $(\mathrm{p}>0.05)$.

중성지방은 운동군이 $120.53 \pm 14.42 \mathrm{mg} / \mathrm{dl}$ 에서 12주 운동 후 $113.20 \pm 15.88 \mathrm{mg} / \mathrm{dl}$ 로 통계적으로 유의하게 감 소하였고 $(\mathrm{p}<0.05)$, 대조군은 $119.13 \pm 17.49 \mathrm{mg} / \mathrm{dl}$ 에서 $119.20 \pm 18.41 \mathrm{mg} / \mathrm{dl}$ 로 통계적으로 유의한 차이가 없었다 $(\mathrm{p}>0.05)$.

$\mathrm{HDL}$ 콜레스테롤은 운동군이 $46.66 \pm 9.44 \mathrm{mg} / \mathrm{dl}$ 에서 12 주 운동 후 $48.28 \pm 8.84 \mathrm{mg} / \mathrm{dl}$ 로 통계적으로 유의하게 증가하였고 $(\mathrm{p}<0.05)$, 대조군은 $47.46 \pm 8.17 \mathrm{mg} / \mathrm{dl}$ 에서 $46.24 \pm 7.59 \mathrm{mg} / \mathrm{dl}$ 로 통계적으로 유의한 차이가 없었다 $(\mathrm{p}>0.05)$.

LDL 콜레스테롤은 운동군이 $102.36 \pm 19.69 \mathrm{mg} / \mathrm{dl}$ 에서 12 주 운동 후 $93.05 \pm 20.63 \mathrm{mg} / \mathrm{dl}$ 로 통계적으로 유의하게 감소하였고 $(\mathrm{p}<0.05)$, 대조군은 $98.88 \pm 21.51 \mathrm{mg} / \mathrm{dl}$ 에서 $99.73 \pm 20.10 \mathrm{mg} / \mathrm{dl}$ 로 통계적으로 유의한 차이가 없었다 $(\mathrm{p}>0.05)$.

Table 3. Changes of body composition

$(n=30)$

\begin{tabular}{|c|c|c|c|c|}
\hline variable & group & pre & post & $\mathbf{p}$ \\
\hline \multirow{3}{*}{ Weight $(\mathrm{kg})$} & Control & $57.13(6.35)^{\mathrm{a}}$ & $57.06(5.37)$ & 0.499 \\
\hline & aquarobic & $59.00(5.14)$ & $57.93(5.03)$ & $0.027^{*}$ \\
\hline & $\mathrm{p}$ & 0.539 & 0.372 & \\
\hline \multirow{3}{*}{ Skelectal muscle mass (kg) } & control & $21.00(2.36)$ & $21.20(2.45)$ & 0.384 \\
\hline & aquarobic & $21.73(2.93)$ & $22.33(2.91)$ & 0.095 \\
\hline & $\mathrm{p}$ & 0.550 & 0.454 & \\
\hline \multirow{3}{*}{ Body fat percentage $(\%)$} & control & $32.26(4.86)$ & $32.80(4.82)$ & 0.527 \\
\hline & aquarobic & $32.20(4.61)$ & $30.06(3.75)$ & $0.002^{* *}$ \\
\hline & $\mathrm{p}$ & 0.625 & 0.217 & \\
\hline
\end{tabular}

Values are presented as mean (SD) ${ }^{\mathrm{a}}$ 
Table 3. Changes of cardiovascular index

$(\mathrm{n}=30)$

\begin{tabular}{|c|c|c|c|c|}
\hline variable & group & pre & post & $\mathbf{p}$ \\
\hline \multirow{3}{*}{ Total cholesterol (mg/dl) } & control & $190.93(32.78)^{\mathrm{a}}$ & $191.00(32.14)$ & 0.680 \\
\hline & aquarobic & $191.33(34.06)$ & $175.60(30.50)$ & $<0.001^{* * *}$ \\
\hline & $\mathrm{p}$ & 0.345 & 0.725 & \\
\hline \multirow{3}{*}{ Triglyceride (mg/dl) } & control & $119.13(17.49)$ & $119.20(18.41)$ & 0.655 \\
\hline & aquarobic & $120.53(14.42)$ & $113.20(15.88)$ & $0.023^{* *}$ \\
\hline & $\mathrm{p}$ & 0.596 & 0.711 & \\
\hline \multirow{3}{*}{ HDL cholesterol (mg/dl) } & control & $47.46(8.17)$ & $46.24(7.59)$ & 0.317 \\
\hline & aquarobic & $46.66(9.44)$ & $48.28(8.84)$ & $<0.001^{* * *}$ \\
\hline & $\mathrm{p}$ & 0.408 & 0.357 & \\
\hline \multirow{3}{*}{ LDL cholesterol (mg/dl) } & control & $98.88(21.51)$ & $99.73(20.10)$ & 0.589 \\
\hline & aquarobic & $102.36(19.69)$ & $93.05(20.63)$ & $0.008^{* *}$ \\
\hline & $\mathrm{p}$ & 0.588 & 0.680 & \\
\hline
\end{tabular}

Values are presented as mean $(\mathrm{SD})^{\mathrm{a}}$

\section{고찰}

본 연구는 60 세 이상 여성노인을 대상으로 12 주간 아 쿠아로빅 운동 프로그램을 실시하고 신체조성 및 심혈관 계지표의 변화를 알아보고 지역사회 건강증진 프로그램의 기초자료로 활용하고자 실시하였다.

규칙적인 운동은 체지방율 감소시켜 비만을 예방하고, 혈중지지 수준을 개선하여, 질병에 의한 사망률을 낮추는 것으로 알려져 있다[21]. White[22]는 수중운동이 관절의 움직임 증가와 통증감소 등의 신체적 문제점을 개선시켜 만성질환 환자나 근골격계가 약하면서 지방이 많은 노년 기 여성에게 적합한 운동 프로그램이라고 주장하여 수중 운동은 본 대상자에게 적합한 운동이라고 할 수 있다.

본 연구에서 수중운동 프로그램 후의 신체조성의 변화 를 보면, 체중, 체지방율은 감소하였는데 비해 근육량은 증가하는 경향을 보였다. 지용석 등[23]은 48주간 노인을 대상으로 규칙적인 수중운동을 적용한 결과 체중과 체지 방이 통계적으로 유의하게 감소하였다고 보고하였고, 이 경옥 등[6]도 여성을 대상으로 총12주간 주 3회 아쿠아로 빅 운동프로그램에 적용하여 체지방율이 통계적으로 유의 하게 감소하였다고 보고하여 본 연구결과와 일치하였다. 이러한 결과는 규칙적인 아쿠아로빅 운동으로 체 내 지방 의 감소와 근육량의 증가가 나타난 것으로 판단되며, 임 호남[24]도 체중, 체지방량 및 체질량지수가 감소하였다 는 것은 수중에서의 아쿠아로빅 운동의 실시로 지방이 감 소했다고 주장하여 본 연구결과를 지지하고 있다.

총콜레스테롤은 흡연여부, 고혈압과 함께 관상동맥경화 등 혈관질환에서 3 대 위험인자로 알려져 있으며, 총콜레
스테롤의 수치가 높으면 높을수록 관상동맥질환의 발병률 이 증가하게 되고, 낮으면 낮을수록 발병률이 감소한다는 보고를 함으로써 혈중지질에 대한 적극적인 관리의 중요 성이 강조되고 있다[23]. 다양한 관리방안 중 규칙적인 운 동은 총콜레스테롤의 감소에 많은 영향을 미치며, 운동강 도는 최대산소섭취량 $(\mathrm{VO} 2 \mathrm{max})$ 의 $50-85 \%$ 로 장기간 시행 하였을 때 총콜레스테롤이 낮아진다고 보고되고 있다[20]. 중년여성을 대상으로 하여 본 연구기간과 같이 12 주간의 유산소 운동을 시행하였을 때 총콜레스테롤이 감소되었고 [25], 노인여성을 대상으로 16주간의 수중운동 후 총콜레 스테롤은 감소되어[26] 본 연구의 결과와 일치했다.

총콜레스테롤은 혈중 지질의 한 형태로 중성지방이 높 을 경우 동맥경화나 관상동맥 질환의 위험도가 높아지기 에 심혈관 질환 관련 중요한 지표로 활용되고 있다. 본 연 구에서도 12 주간의 아쿠아로빅 운동의 효과를 알아보기 위해 총콜레스테롤을 분석한 결과 12주간 아쿠아로빅 운 동을 시행한 그룹에서 통계적으로 유의한 차이가 나타났 다. 강대관[27], 지용석[23]등은 수중운동이 중년여성의 총콜레스테롤, 중성지방, $\mathrm{LDL}, \mathrm{HDL}$ 의 개선에 효과가 있 다고 보고하였고, 정덕조 등[16]의 중년 비만여성을 대상 으로 한 연구에서도 아쿠아로빅 운동 후 총콜레스테롤의 개선에 효과가 있다고 보고하여 본 연구결과를 지지하고 있다.

이러한 결과는 혈중지질 중 규칙적인 운동과 매우 밀접 한 관련이 있는 총콜레스테롤과 $\mathrm{HDL}$ 콜레스테롤이 12주 간의 규칙적인 아쿠아로빅 운동으로 인해 지단백질 리파 아제나 간 리파아제와 같은 여러 효소들이 활성화 됨에 따라 중성지질의 분해가 촉진되고 $\mathrm{HDL}$ 콜레스테롤의 생 
산도 증가되어 나타난 결과로 생각된다[28].

$\mathrm{HDL}$ 콜레스테롤도 혈중지질의 한 형태로 $\mathrm{HDL}$ 콜레스 테롤이 높을 경우 동맥경화나 관상동맥질환의 위험도가 낮아지는 것으로 알려져 있으며, 혈중지질 분석시 총콜레 스테롤, $\mathrm{LDL}$ 콜레스테롤과 함께 시행되고 있다. 또한 $\mathrm{HDL}$ 콜레스테롤은 관상동맥질환의 위험을 감소시키고 혈 관에 지질이 축적되는 것을 막는 작용을 하며, 국소혈관 조직에서 총콜레스테롤을 제거하는 작용을 한다.

강대관[27]은 비만 여성을 대상으로 한 12 주 수중운동 은 $\mathrm{HDL}$ 콜레스테롤의 유의한 증가의 효과가 있다고 보고 하였고, 한승완[29]은 고혈압 환자 중 중년여성을 대상으 로 아쿠아로빅 운동을 실시한 결과 HDL콜레스테롤의 유 의한 증가를 가져왔다고 보고하여 본 연구결과와 일치 하 였다.

$\mathrm{LDL}$ 콜레스테롤은 간으로부터 말초조직으로 운반하는 주요한 운반체로서 동맥혈관 내막의 지단백 가운데 콜레 스테롤을 작용시켜 $\mathrm{LDL}$ 콜레스테롤은 높을수록 동맥경화 나 관상동맥질환의 위험도가 높아지는 것으로 알려져 있 다[30].

황연희와 김동희[2]은 비만노인여성을 대상으로 아쿠아 로빅 운동후 통계적으로 유의하게 감소하였다고 보고하였 고, 이명천과 장유정[31]의 연구에서도 노인여성을 대상 으로 수중운동을 실시하여 LDL콜레스테롤이 통계적으로 유의하게 감소하였다고 보고 하여 본 연구결과와 일치하 였다. 이러한 결과는 12 주간의 규칙적인 아쿠아로빅 운동 프로그램이 총콜레스테롤을 낮추게 되며 혈중 지단백 분 해효소의 활성화 및 $\mathrm{HDL}$ 콜레스테롤 증가로 인해 나타난 결과로 생각된다.

본 연구는 대상자를 편의추출하여, 대상자들의 스트레 스 및, 식이습관 등을 통제하지 못하였다. 또한 12 주간의 아쿠아로빅 운동프로그램에 15 명을 시행하여 일반화시키 기에는 어려움이 따른다. 그럼에도 불구하고 본 연구는 지역사회 건강증진 프로그램을 12 주간 아쿠아로빅 운동으 로 실시하여 신체조성 및 심혈관지표를 정량적으로 분석 함으로써 지역사회 건강증진 프로그램에 대한 기초자료를 제시함에 그 의의가 있다.

향후 연구에서는 다양한 연령, 성별에 따른 비교 연구 및 만성질환자 등을 대상으로 한 지역사회 운동프로그램 으로서의 아쿠아로빅 운동의 효과에 대한 연구, 또한 아 쿠아로빅 운동프로그램의 동작에 따른 분석 연구 등이 필 요하리라 사료된다.

\section{결론}

본 연구는 지역사회 건강증진 프로그램을 통한 아쿠아 로빅 운동프로그램이 노인여성의 신체조성 및 심혈관계
지표에 어떠한 효과가 있는지 확인하기 위해 65 세 이상 노인여성을 대상으로 시행하였다. 연구결과 규칙적인 아 쿠아로빅 운동이 비만 감소 및 혈중 지질의 감소가 있음 을 확인하였다. 따라서 향후 지역사회 운동프로그램 운영 시 아쿠아로빅 운동이 포함된 프로그램의 계획 및 시행이 필요할 것으로 사료된다.

\section{감사의 말}

본 연구는 2021년도 광주보건대학교 교내연구비의 지 원을 받아 수행된 연구임(No. 2021013).

\section{이해 충돌}

본 연구의 저자들은 연구,저작권 및 출판과 관련하여 잠재적인 이해충돌이 없음을 선언합니다.

\section{참고문헌}

1. Statistical Office. 2020 Elderly person statistics investigation. 2020.

2. Hwang YH, Kim DG. The Effects of Aquarobic Exercise Program on Body Composition and Blood Lipid Concentrations in Obese Elderly Females. Korea Academy Industrial Cooperation Society. 2016;17:226-232.

3. Lee JM, LEE JY. Effects of aerobic exercise training on bone mineral density and arterial stiffness in elderly women. Korean Journal of Sports Science. 2011;20:1181-89.

4. Shiran A, Weissman J, Leiboff B, Kent KM, Pichard A, Satler LF, et al. Effect of preintervention plaqe burden of subsequent intimal hyperplasia in stented coronary artery lesions. Am J Cardiol. 2000;86: 1318-21.

5. Kim HC. The effects of 12-week aerobic complex training and exercise intensities on \%body fat, cardiovascular function, MDA, CRP, and homocysteine level in obese women of the elderly. Chungbuk University;2006.

6. Lee KO, Lee GW, Lee YC, Han HW, Kim HE. The Effects of Aquarobics Exercise on Women's Physique, Physical Fitness and Body Composition. Korean journal of physical education. 2000;39: 436-44.

7. Froidevax F, Schutz Y, Christin L, E Jéuier. 
Energy expenditure in obese women before and during weight loss, after refereeing, and in the weight-relapse period. Am J Clin Nutr. 1993;57: 35-42.

8. Um SY, Kwak YS. The effects of regular exercise on cognitive function and blood Lipid in woman patient with senile dementia. Korean Journal of Sport Science. 2004;15:57-65.

9. Brown WJ, McLaughlin D, Leung J, McCaul KA, Flicker L, Almeida OP, et al. Physical activity and all-cause mortality in older women and men. $\mathrm{Br} \mathrm{j}$ sports Med. 2012;46:664-8.

10. Booth FW, Gordon SE, Carlson CJ, Hamilton MT. Waging war on modern chronic diseases; primary prevention through exercise biology. J. Appl. Physiol. 2000;88:774-87.

11. Tanaka H. Habitual exercise for the elderly. Family \& Community Health. 2009;32(1):57-65.

12. Kim HK, Kim MJ. of Weight Control Program on Dietary Habits and Blood Composition in Obese Middle-Aged Women. Journal of Nutrition and Health. 2010;43:273-84.

13. Rahmann AE, Brauer SG, Nitz JC. A specific inpatient aquatic physiotherapy program improves strength after total hip or knee replacement surgery: a randomized controlled trial. Arch Phys Med Rehabil. 2009;90:745-55.

14. McNeal RL. Aquatic therapy for patient with rheumatic disease. Rheumatic Disease Clinical. 1990;18: 915-25.

15. Kim CS, Jang SH, Kim YJ, Park MH, Lee SJ. The Effects of an Aquarobics Exercise Program on the Physical Fitness and Blood Lipids in Elderly Women. Korean Society for Environmental Sanitary Engineers. 2009;24:49-59.

16. Jung DJ, Choi DE, Chung JW. The Effect of Aquarobics on Metabolic Syndrome Risk Factors in Middle-aged Women. Journal of Korean Physical Education Association for Girls and Women. 2009;23:45-56.

17. Kim IS. The Effect of an Aquarobic Exercise Program on the Self-Efficacy, Pain, Body Composition, Blood Lipid and Depression in women with Osteoarthritis. Chonbuk;2009.

18. Wilder PR, Brennan DK. Physiological response to deep water running in athletes. Sports Medicine.
1999;16: 374-80

19. Jones CJ, Rose DJ. Physical activity instruction of older adults. Illinois: Human Kinetics Publishers. 2005.

20. ACSM. ACSM's guidelines for Exercise Testing and Prescription(8th ed): New York: Lippincott Williams and Wilkins. 2010.

21. Lim MJ. Effects of 8 week - exercise on Fat Distribution, Cardiovascular Fitness, Lipid profiles and Plasma Homocysteine Concentration in Elderly Obese Women. The Korean journal of obesity. 2000;9: 237-45.

22. White M. Water Exercise. Illinois: Human Kinetics Publishers. 1995.

23. Jee YS, Kim MK. Choi YS. Seo TB, Lee SK, et al. The effects of 48 weeks aqua - exercise on blood lipid profile and body composition of elderly women. Korean journal of physical education. 2001;40:717-31.

24. Lee HN. The Effect of Water Exercise on Body Composition, Bone Mineral Density and Health Related Fitness of the Elderly Women. Journal of Korean Physical Education Association for Girls and Women. 2009;23:39-48.

25. Kim HJ. Effect of aerobic exercise according to the presence of exercise experience on body composition and blood lipids in middle-aged obese women. Kook Min University;2005.

26. Jin HM, Suk HW. Influence of Aquatic Exercise in Body Composition and Circulating Lipid of Elder Women. Journal of Korean Physical Education Association for Girls and Women. 2004;18: 41-9.

27. Kang DK. The effects of aquatic exercise on cardiovascular risk factors and metabolic regulatory hormone in the woman obesity and hypertension. Korean Journal of Sports Science. 2008;17:651-60.

28. Lee MC, Jang YJ. Effect of 12-week aquatic exercise on weight, percent body fat, serum glucose, and serum Lipids on elderly women. Korean journal of physical education. 2008.

29. Han SW. Effects of the Difference of Exercise Intensity of Hypertensive Patients on Blood Pressure, Serum Lipid. Journal of Sport and Leisure Studies. 2007;31:1291-1300.

30. Ko SH, Ha SM, Kim JH, Ha MS, Hyun SJ, et al. Effects of 12-week aquarobics exercise on the 
blood lipids, atherogenic index and liver functions of elderly women. Journal of Oil \& Applied Science. 2018;35:1185-96.

31. Lee MC, Jang YJ. Effect of 12-week aquatic exercise on weight, percent body fat, serum glucose, and serum Lipids on elderly women. The Korean journal of physical education. 2009;48:401-409. 